\title{
STRATEGI PEMASARAN PT X DALAM MENINGKATKAN PENJUALAN
}

\author{
Sudiman \\ Program Studi Magister Manajemen Universitas Tarumanagara \\ sudirman.sudjana@gmail.com
}

\begin{abstract}
Aim of this thesis is to analyze PT X, a chemical distribution company, and find which strategy can help this company increase sales and survive in competition. First with analyzes the external environmental conditions and advantages possessed by PT X. Then with the SOAR method combine with Offensive and Defensive Competitive Strategy, position and strategy for PT X can be determine. This strategy can help PT X maximize internal strength and take advantages of existing opportunities from external to meet the aspirations and wishes of stakeholders. The conclusion of this thesis found that PT $\mathrm{X}$ is follower and need to use attack strategy, which can increase market share. Increase number of customers, increase type of products, and improve service also key factors which can make PT X increase sales.
\end{abstract}

Keywords: Chemical distribution company, increase sales, follower, attack strategy

\section{PENDAHULUAN}

Pada tahun 2016, pasar ritel untuk cat dekoratif dan pelapis di Indonesia sekitar USD785,3 juta. Secara historis, pasar cat Indonesia telah tumbuh dengan Compound Annual Growth Rate (CAGR) di sekitar 7,2\% antara tahun 2011 dan 2016 dan diperkirakan akan mencapai USD1.206,3juta pada tahun 2021, dengan asumsi perkiraan CAGR sekitar 9,0\% selama periode 2016 sampai 2021. (Frost \& Sullivan, 2017).

\section{Gambar 1. Pertumbuhan Decorative Retail Market di Beberapa Negara ASEAN}

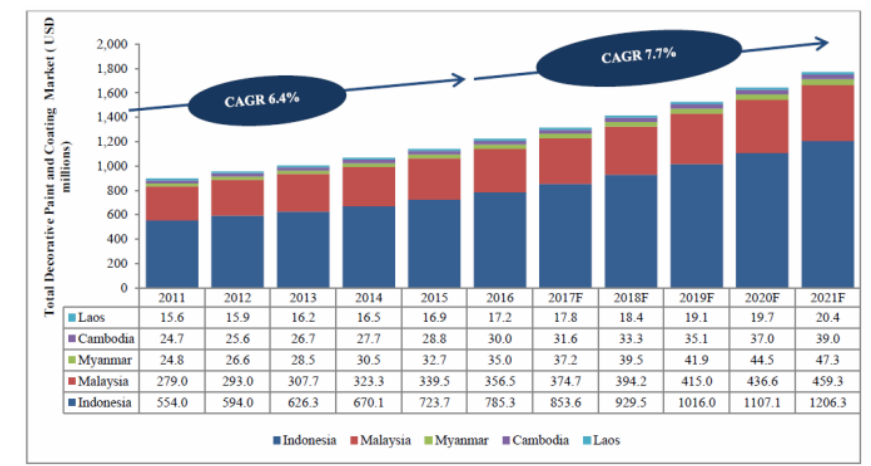

Sumber: Frost \& Sullivan "Independent Market Research on the Paint and Coating Southeast Asian Countries", Mei 2017, hal 58.

Kebergantungan akan bahan baku impor untuk pewarna di industri cat menjadi peluang untuk perusahaan importir bahan kimia untuk menjadi pemasok ke industri cat. Tabel 1. di bawah memperlihatkan besaran impor dari bahan kimia pewarna berbentuk powder di luar dari titanium dioxide. 
Tabel 1. Tabel Impor Pewarna Padat 2014-2015 diluar Titanium Dioxide

\begin{tabular}{|c|c|c|c|c|c|}
\hline \multirow[t]{2}{*}{ HS Code } & \multirow[t]{2}{*}{$\begin{array}{l}\text { COMMODITY } \\
\text { DESCRIPTION }\end{array}$} & \multicolumn{2}{|c|}{ Jan-Des 2014} & \multicolumn{2}{|c|}{ Jan-Des 2015} \\
\hline & & $\begin{array}{c}\text { Net } \\
\text { weight } \\
(\mathrm{Kg})\end{array}$ & $\begin{array}{l}\text { CIF value } \\
\text { (USD) }\end{array}$ & $\begin{array}{c}\text { Net } \\
\text { weight } \\
(\mathrm{Kg})\end{array}$ & $\begin{array}{l}\text { CIF value } \\
\text { (USD) }\end{array}$ \\
\hline $\begin{array}{r}32041700 \\
10\end{array}$ & $\begin{array}{l}\text { SYNTHETIC ORGANIC } \\
\text { PIGMENT IN POWDER } \\
\text { FORM }\end{array}$ & $9,118,640$ & $\begin{array}{r}80,759,04 \\
2\end{array}$ & $7,563,630$ & $\begin{array}{r}69,409,62 \\
2\end{array}$ \\
\hline $\begin{array}{r}32062010 \\
00 \\
\end{array}$ & $\begin{array}{l}\text { CHROME } \\
\text { YELLOW,CHROME } \\
\text { GREEN,MOLYBDATEORAN } \\
\text { GE/ RED BASE ON } \\
\text { CHROMIUM COMPOUND }\end{array}$ & $1,633,775$ & $6,533,642$ & $1,475,985$ & $5,432,942$ \\
\hline $\begin{array}{r}32064190 \\
00 \\
\end{array}$ & ULTRAMARINE & $1,709,421$ & $3,779,019$ & $1,689,043$ & $3,246,906$ \\
\hline & TOTAL & $\begin{array}{r}12,461,83 \\
6\end{array}$ & $\begin{array}{r}91,071,70 \\
3\end{array}$ & $\begin{array}{r}10,728,65 \\
8\end{array}$ & $\begin{array}{r}78,089,47 \\
0\end{array}$ \\
\hline
\end{tabular}

Sumber: Statistik Perdagangan Luar Negeri Indonesia - Impor 2015

David (2013) menyatakan bahwa "Proses manajemen strategi didasarkan pada kepercayaan bahwa perusahaan harus selalu memonitor kejadian internal dan eksternal dan trend sehingga perubahan secara kontinu dapat dilakukan bila diperlukan. Banyaknya dan besarnya perubahan yang berpengaruh terhadap perusahaan meningkat pesat, terbukti dengan bagaimana resesi ekonomi global telah memberi kejutan bagi banyak perusahaan. Perusahaan seperti mahluk hidup harus mahir beradatasi atau tidak akan bertahan" (p. 37).

Menyadari pentingnya proses manajeman strategi seperti yang ditulis oleh David (2014) di atas, maka diperlukan sebuah analisa eksternal dan internal perusahaan yang dapat membantu PT X untuk bertahan dan mengembangkan pemasarannya.

Tujuan dari makalah ini dibuat untuk memahami faktor lingkungan eksternal, internal, dan lingkungan persaingan dari PT X. Selanjutnya diterapkan strategi pemasaran yang sesuai, sehingga dapat membantu PT X untuk meningkatkan penjualan.

\section{TELAAH KEPUSTAKAAN}

Kotler dan Armstrong (2016) menuturkan bahwa manajemen pemasaran merupakan "art and science of choosing target and getting, keeping, and growing customer through creating, delivering and communicating superior customer value".

\section{Pengertian Business to Business (B2B)}

Kumar dan Reinartz (2012) mendeskripsikan Business to Business sebagai "The form of relationship with the company on the side of supplier and another business company on the customer side. This business company could be represented by sole trader, company or institution" (p.261).

\section{Analisis Lingkungan Eksternal dan Internal}

Dalam menetapkan strategi pemasaran, perusahaan harus mengetahui tujuan yang akan dicapai dan mengenal lingkungan industri serta produk apa yang harus difokuskan. 


\section{Analisis Lingkungan Eksternal}

Menurut Pearce dan Robinson (2011) lingkungan eksternal adalah faktor di luar kendali perusahaan yang dapat mempengaruhi. Hal yang perlu diperhatikan adalah:

A. Lingkungan Ekonomi seperti: Produk Domestik Bruto (PDB), nilai tukar, inflasi, tingkat pengangguran, Upah Minimum Regional (UMR), tingkat suku bunga.

B. Lingkungan Politik dan Hukum

C. Lingkungan Teknologi

D. Lingkungan Sosial Budaya

\section{Analisis Lingkungan Industri (Five Forces Porter)}

Porter (2008) menjelaskan mengenai lima kekuatan yang mempengaruhi persaingan dalam suatu industri (The Five Forces Model of Competition), yaitu: ancaman masuknya pendatang baru, kekuatan tawar menawar pemasok, kekuatan tawar menawar pembeli, ancaman produk substitusi, dan persaingan dalam industri.

\section{Analisis Lingkungan Internal}

Pearce \& Robinson (2011) menjelaskan bahwa pemimpin bisnis melihat peluang pasar tidak hanya pada peluang eksternal, tetapi juga pada kesadaran pada keunggulan dari internal perusahaan. Faktor internal yang penting untuk dianalisa: pemasaran, keuangan, Research and Development (R\&D), operasi, sumber daya manusia (Human Resource), sistem informasi dan teknologi.

\section{Analisis SOAR}

Stavros \& Kelley (2003) menawarkan konsep SOAR (Strengths, Opportunities, Aspirations, Results) yang berasal dari pendekatan Appreciative Inquiry (AI). Pendekatan AI lebih menitikberatkan pada pengidentifikasian kekuatan dan peluang ketimbang pada kelemahan, dan ancaman.

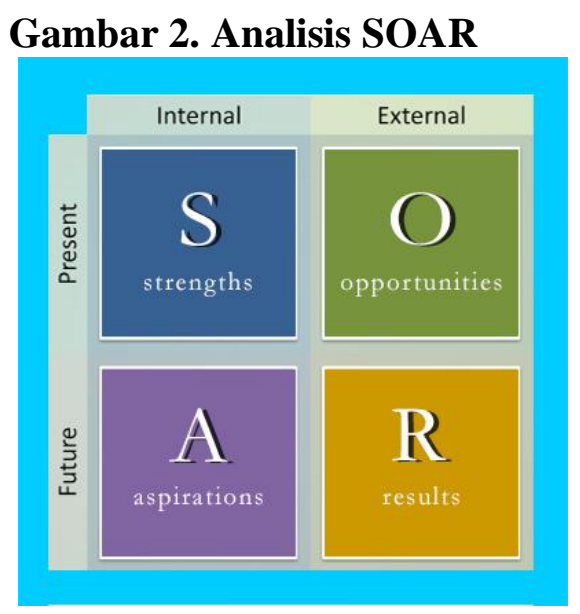

Sumber: Stavros \& Kelley (2003).

Deskripsi mengenai SOAR sebagai berikut:

1. Strength (S): Hal-hal yang menjadi kekuatan serta aset terbesar yang dimiliki diungkapkan, baik aset yang berwujud maupun aset yang tidak berwujud.

2. Opportunities $(\mathrm{O})$ Berarti dilakukannya analisis terhadap lingkungan eksternal guna mengidentifikasi peluang terbaik yang dimiliki.

3. Aspirations (A) Para anggota organisasi berbagi aspirasi dan merancang kondisi masa depan yang mereka impikan.

4. Results (R) Berarti menentukan ukuran dari hasil-hasil yang ingin dicapai (measurable results). 


\section{Offensive and Defensive Competitive Strategy}

Untuk terus bersaing, perusahaan perlu mencari cara untuk memperbesar permintaan dari pasar. Kotler \& Keller (2012) membagi strategi menjadi:

1. Memperbesar permintaan pasar total

Dapat dilakukan dengan cara menambah pelanggan baru, melindungi penggunaan produk, menjadi penantang baru, menjadi pengikut pemimpin pasar, dan memenuhi pasar yang khusus (Niche market)

2. Attack Strategy

Untuk meningkatkan pasar, dapat dilakukan melalui menyerang langsung (Frontal Attack), bergerak cepat dan mengisi celah (Flank Attack), menyerang beberapa sisi (Encirclement Attack), menyerang pasar yang mudah (Bypass Attack), melakukan penyerangan gerilya (Guerilla Attack).

3. Defensive Strategy

Untuk mengurangi kesempatan diserang, dapat dilakukan melalui menduduki posisi aman (Position Defence), mendirikan perlindungan (Flank Defence), menyerang lebih dulu (Preemptive Defence), menyerang sisi samping (Countreoffensive Defence), menyerang pasar yang lemah untuk melindungi pasar yang kuat (Contraction Defence).

\section{Segmentation, Targeting, and Positioning (STP)}

Kotler \& Keller (2012) mengatakan bahwa "Semua pemasaran dibangun dengan STP - Segmentasi, Target dan Pemosisian”. Penjelasannya sebagai berikut:

1. Segmentasi Pasar (Segmentation)

Segmentasi pasar B2B adalah aset penting bagi perusahaan. Sejauh mana segmentasi digunakan di pasar industri dapat bervariasi dan bergantung pada perubahan kondisi di lingkungannya. Itu juga tergantung pada kebutuhan organisasi dan jenis kegiatannya. (Hutt \& Speh, 2013)

2. Target Pasar (Targeting)

Jobber (2009) mendefinisikan bahwa "target pasar adalah segmen pasar yang dipilih oleh perusahaan untuk dilayani".

3. Pemosisian (Positioning)

Pemosisian adalah tindakan merancang suatu produk dan mereknya untuk menempati tempat tertentu di pasar sasaran. Tujuan utamanya adalah menciptakan merek di pikiran konsumen agar perusahaan mendapatkan keuntungan sebanyak mungkin (Kotler \&Keller, 2012).

\section{Bauran Pemasaran (Marketing Mix)}

Menurut Kotler dan Armstrong (2016), bauran pemasaran adalah kumpulan alat pemasaran taktis terkendali yang dipadukan perusahaan untuk menghasilkan respon yang diinginkannya di pasar sasaran. Bauran pemasaran menurut Dogra (2010) mencakup 4P:

1. Product

Kotler \& Keller (2012) mengatakan produk adalah sesuatu yang dapat ditawarkan ke pasar untuk memuaskan keinginan atau kebutuhan, baik berbentuk fisik atau non fisik.

2. Price

Kotler \& Keller (2012) mengatakan harus mempertimbangkan banyak faktor dalam membuat keputusan penetapan harga yaitu perusahaan, pelanggan, persaingan, dan lingkungan pemasaran.

3. Place 
Kotler \& Keller (2012) mengatakan saluran pemasaran melakukan pekerjaan memindahkan barang dari produsen ke konsumen.

4. Promotion

Bauran promosi merupakan semua aktivitas yang dilakukan untuk membuat produk atau jasa diketahui dan disukai oleh pengguna. Menurut Kotler \& Keller (2012) bauran promosi terbagi menjadi komunikasi massal dan komunikasi personal.

\section{METODOLOGI PENELITIAN}

Pengumpulan data pada makalah ini menggunakan metode exploratory dan metode deskriptif yang menggambarkan keadaaan PT X, dijelaskan secara detail berdasarkan faktafakta yang ada dan disertai interpretasi kegiatan perusahaan yang sebenarnya. Pengumpulan data seperti kondisi lingkungan eksternal, kondisi internal perusahaan, data penjualan, dan aspirasi dari stakeholder untuk mendukung penulisan makalah ini diperoleh dengan cara:

1. Penelitian lapangan (Field Research) yaitu observasi, wawancara dan meeting internal perusahaan.

2. Penelitian kepustakaan (Library Research) yaitu text book, website, dan data dari Badan Pusat Statistik.

\section{ANALISIS DAN BAHASAN TEMUAN}

\section{Analisis Lingkungan Eksternal}

Perusahaan harus menganalisa faktor eksternal yang terjadi pada suatu waktu untuk menetapkan strategi dan memanfaatkan peluang. Berikut adalah analisa dari faktor eksternal yang dapat dijadikan peluang (opportunity) pada saat makalah ini dibuat:

1. Lingkungan Ekonomi

- PDB Indonesia meningkat

\section{Gambar 3. Grafik PDB Indonesia}

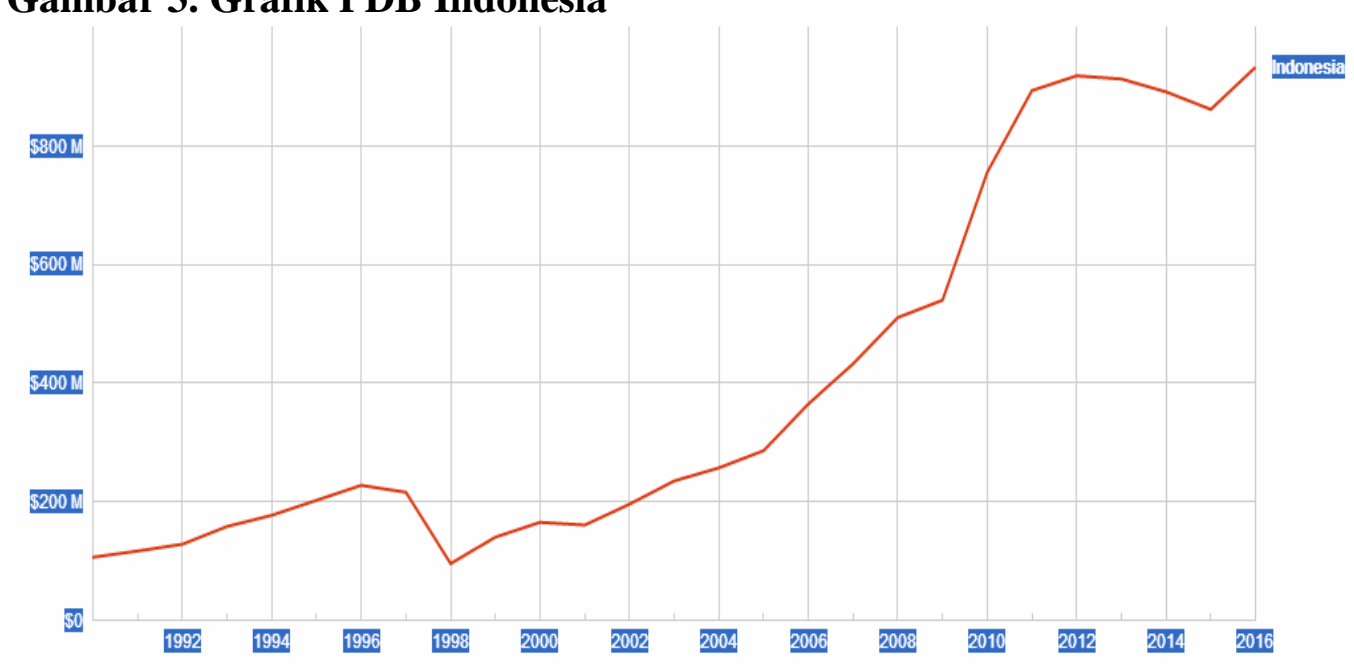

Sumber: World Bank

- Sejak 2015 inflasi Indonesia stabil di kisaran 3\%

Gambar 4. Data Inflasi 2014-2017 


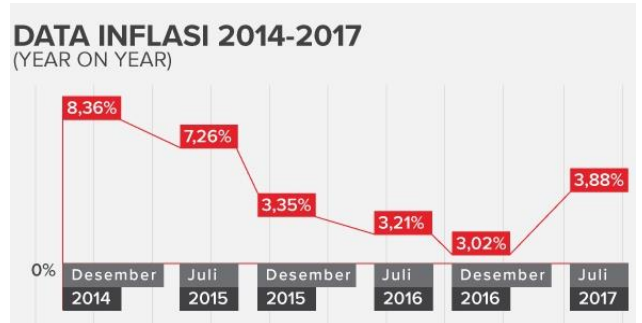

Sumber: Website CNN Indonesia.

2. Lingkungan Politik dan Hukum

Peringkat kemudahan berusaha di Indonesia membaik, hal ini dinyatakan oleh Bank Dunia yang meningkatkan peringkat EODB Indonesia pada tahun 2018 menjadi posisi 72 .

3. Lingkungan Teknologi

Kemajuan teknologi mempermudah proses bisnis dan analisa bisnis.

4. Lingkungan Sosial Budaya

Tingginya penduduk usia produktif, hal ini terlihat dari piramida penduduk Indonesia.

Dari hasil di atas, kondisi eksternal mendukung untuk berusaha, terlihat dari meningkatnya PDB, kemudahan berusaha, adanya dukungan teknologi dan tenaga kerja.

\section{Analisis Lingkungan Industri (Five Forces Porter)}

Berikut adalah hasil analisis lingkungan industri:

\section{Ancaman Masuknya Pendatang Baru}

Terdapat beberapa hal yang dapat menjadi hambatan masuk dari pesaing baru yaitu: differensiasi produk, kebutuhan modal, keuntungan biaya dari lainnya, kebijakan pemerintah, dan pemasok. Adanya hambatan ini membuat pendatang baru tidak mudah memasuki bisnis ini.

\section{Kekuatan Tawar Menawar Pemasok}

Industri hulu ini memiliki kemampuan untuk tawar menawar. Industri hulu ini juga kerap kali melakukan integrasi maju, sehingga dapat mengontrol harga di pasar.

3. Kekuatan Tawar Menawar Pembeli

Hampir tidak ada bahan baku yang tidak memiliki kompetisi dalam industri cat dan pabrik cat yang besar atau Multi National dapat menekan harga.

\section{Ancaman Produk Substitusi}

Tidak banyak penjual dengan kemampuan dapat melihat tingkat kebutuhan konsumen membuat distribusi kimia tidak mudah untuk ancaman produk substitusi.

\section{Intensitas Persaingan}

Persaingan dalam industri ini ketat karena bertambahnya perusahaan dengan modal besar memasuki pasar, beberapa perusahaan distribusi kimia lain melakukan diversifikasi ke cat, dan pertumbuhan industri cat yang melambat

Dari analisa di atas terlihat industri bahan kimia cat adalah industri dengan persaingan yang tinggi. Tapi industri ini tetap menarik karena jumlah pertumbuhan penduduk Indonesia yang besar, sehingga permintaan cat akan selalu meningkat. 


\section{Analisis Lingkungan Internal}

Berikut adalah hasil kekuatan (strength) PT X dari analisa lingkungan internal:

1. Pemasaran

PT X sudah hampir 25 tahun menjalankan bisnis bahan baku kimia pewarna ke industri cat sehingga cukup dikenal.

2. Keuangan

Memiliki modal yang kuat, hal ini dapat terlihat dengan penghapusan pinjaman ke bank untuk modal kerja pada 2018.

3. Research and Development

Memiliki laboratorium dan chemist yang berpengalaman

4. Operasi

Memiliki gudang dan armada pengiriman sendiri.

5. Sumber daya manusia

Memiliki divisi human resource yang melakukan seleksi dan pelatihan karyawan.

6. Sistem Teknologi Informasi

Memiliki divisi IT yang dapat membantu analisa data.

\section{Posisi dalam Persaingan Usaha}

Berikut adalah posisi PT X dalam persaingannya:

Tabel 2. Tabel Penjualan Pewarna Padat 2014-2015 diluar Titanium Dioxide dari PT X Dibandingkan dengan Total Impor Indonesia.

\begin{tabular}{|c|c|c|c|c|c|}
\hline \multirow[t]{2}{*}{ HS Code } & \multirow[t]{2}{*}{$\begin{array}{l}\text { COMMODITY } \\
\text { DESCRIPTION }\end{array}$} & \multicolumn{2}{|c|}{$\begin{array}{c}\text { Jan-Des } 2014 \\
(\text { Net weight, } \mathrm{Kg})\end{array}$} & \multicolumn{2}{|c|}{$\begin{array}{c}\text { Jan-Des } 2015 \\
(\text { Net weight, } \mathrm{Kg})\end{array}$} \\
\hline & & $\begin{array}{l}\text { Total } \\
\text { Impor }\end{array}$ & PT X & $\begin{array}{l}\text { Total } \\
\text { Impor }\end{array}$ & PT X \\
\hline $\begin{array}{r}32041700 \\
10\end{array}$ & $\begin{array}{l}\text { SYNTHETIC ORGANIC } \\
\text { PIGMENT IN POWDER } \\
\text { FORM }\end{array}$ & $9,118,640$ & 65,000 & $7,563,630$ & 60,000 \\
\hline $\begin{array}{r}32062010 \\
00\end{array}$ & $\begin{array}{l}\text { CHROME } \\
\text { YELLOW,CHROME } \\
\text { GREEN,MOLYBDATEOR } \\
\text { ANGE/RED BASE ON } \\
\text { CHROMIUM } \\
\text { COMPOUND }\end{array}$ & $1,633,775$ & 100,000 & $1,475,985$ & 75,000 \\
\hline $\begin{array}{r}32064190 \\
00\end{array}$ & ULTRAMARINE & $1,709,421$ & 85,000 & $1,689,043$ & 80,000 \\
\hline & TOTAL & $\begin{array}{r}12,461,83 \\
6\end{array}$ & 250,000 & $\begin{array}{r}10,728,65 \\
8\end{array}$ & $\begin{array}{r}215,00 \\
0\end{array}$ \\
\hline
\end{tabular}

Sumber: Statistik Perdagangan Luar Negeri Indonesia-Impor 2015 dan data penjualan PT X.

Dari Tabel 2. di atas, penjualan PT X berkisar 2\% dari total impor Indonesia. Pada saat makalah ini dibuat, Clariant, Galic Bina Mada, United Chemicals, adalah perusahaan sejenis dengan penjualan lebih besar, sehingga posisi PT X adalah follower. 


\section{Analisis SOAR}

Berikut adalah hasil analisis SOAR dari PT X:

Tabel 3. Matrik SOAR PT X

\begin{tabular}{|c|c|c|}
\hline & STRENGTH & OPPORTUNITIES \\
\hline & $\begin{array}{l}\text { Dikenal customer } \\
\text { Modal kuat } \\
\text { Adanya RnD, HR, IT }\end{array}$ & $\begin{array}{l}\text { Ekonomi membaik, } \\
\text { kemudahan berusaha } \\
\text { Adanya teknologi dan } \\
\text { dukungannya } \\
\text { Banyaknya penduduk } \\
\text { produktif }\end{array}$ \\
\hline ASPIRATION & STRATEGI S-A & STRATEGI O-A \\
\hline $\begin{array}{l}\text { Menjadi supplier kimia } \\
\text { dengan reputasi baik }\end{array}$ & $\begin{array}{l}\text { Meningkatkan service ke } \\
\text { konsumen. RnD mencari } \\
\text { produk berkualitas. }\end{array}$ & $\begin{array}{l}\text { Melakukan penambahan } \\
\text { portofolio produk berkualitas } \\
\text { dan unik }\end{array}$ \\
\hline $\begin{array}{l}\text { Memiliki sistem yang } \\
\text { lebih baik }\end{array}$ & $\begin{array}{l}\text { Jobdesk oleh HR dan sistem } \\
\text { oleh IT sehingga tercipta } \\
\text { sistem yang baik }\end{array}$ & $\begin{array}{l}\text { Mengembangkan teknologi } \\
\text { sehingga dapat tercipta sistem } \\
\text { yang baik }\end{array}$ \\
\hline $\begin{array}{l}\text { Menjadi perusahaan } \\
\text { yang nyaman }\end{array}$ & $\begin{array}{l}\text { Training dan motivasi dari } \\
\text { HR }\end{array}$ & $\begin{array}{l}\text { Memperketat rekrutmen } \\
\text { sehingga diperoleh karyawan } \\
\text { yang memiliki attitude yang } \\
\text { baik }\end{array}$ \\
\hline RESULTS & STRATEGI S-R & STRATEGI O-R \\
\hline Peningkatan penjualan & $\begin{array}{l}\text { Menggabungkan semua } \\
\text { sumber daya internal untuk } \\
\text { meningkatkan penjualan. }\end{array}$ & $\begin{array}{l}\text { Memanfaatkan kondisi } \\
\text { ekonomi sehingga terjadi } \\
\text { peningkatan penjualan }\end{array}$ \\
\hline $\begin{array}{l}\text { Kemudahan proses dan } \\
\text { analisa bisnis }\end{array}$ & $\begin{array}{l}\text { Adanya sistem bisnis yang } \\
\text { mudah dan akurat dengan } \\
\text { bantuan IT }\end{array}$ & $\begin{array}{l}\text { Sistem terintegrasi dengan } \\
\text { dukungan teknologi sehingga } \\
\text { dapat bekerja di luar kantor }\end{array}$ \\
\hline $\begin{array}{l}\text { Turunnya turn over } \\
\text { karyawan }\end{array}$ & $\begin{array}{l}\text { HR menciptakan employee } \\
\text { engagement }\end{array}$ & $\begin{array}{l}\text { Meningkatkan kualitas } \\
\text { karyawan dan komunikasi } \\
\text { antar karyawan dengan } \\
\text { teknologi }\end{array}$ \\
\hline
\end{tabular}

Sumber: hasil analisa internal, analisa eksternal, dan meeting internal PT X

\section{Offensive and Defensive Competitive Strategy}

Dari analisa posisi, diketahui posisi PT X adalah follower, sehingga strategi yang dapat digunakan untuk memperbesar pasar adalah:

1. Memperbesar permintaan pasar total. Hal ini dapat dilakukan dengan:

a. Meningkatkan kinerja sales untuk mendapatkan pelanggan baru dan meningkatkan penetrasi pasar dengan produk yang ada.

b. Melindungi penggunaan produk

Tim sales harus lebih proactive untuk mencari tahu kebutuhan pasar, memprediksi kebutuhan, dan menawarkan solusi ke konsumen.

c. Market-Follower Strategy

Memanfaatkan tim R\&D untuk selalu mencari produk sejenis yang lebih baik.

2. Attack Strategy

PT X harus berusaha menyerang untuk memperbesar pangsa pasar. Strategi menyerang yang dapat digunakan adalah: 
a. Bypass attack dengan memanfaatkan kemampuan R\&D yang ada untuk mencari produk yang lebih baik yang dapat digunakan untuk mengisi pasar yang belum jenuh.

b. Guerilla attack dengan cara menawarkan produk berkualitas yang lebih effisien sehingga dapat memberikan nilai lebih, dan rebate untuk mempertahankan loyalitas konsumen.

\section{Segmentation, Targeting, and Positioning (STP)}

PT X adalah perusahaan yang menjalankan bisnis ke B2B, berikut adalah analisa Segmentation, Targeting, and Positioning (STP) yang dapat dilakukan:

\section{a. Segmentasi Pasar (Segmentation)}

1. Industri yaitu industri pembuat cat yang dapat dikategorikan menjadi industri kecil, sedang dan besar.

2. Karakteristik organisasi adalah semua pabrik cat baik lokal maupun asing.

\section{b. Pasar Sasaran (Targeting)}

1. Berdasarkan ukuran segmen, PT X fokus pada segmen sedang dan besar, karena segmen ini memberikan manfaat ekonomi yang lebih besar dan dapat menerima barang yang lebih berkualitas.

2. Berdasarkan pertumbuhan, PT $\mathrm{X}$ fokus kepada konsumen yang memiliki pertumbuhan dan pengembangan, sehingga dapat menerima produk dengan teknologi baru.

\section{c. Posisi produk (Positioning)}

1. Berdasarkan atribut, PT X memposisikan produknya sebagai produk yang dapat memberikan nilai lebih.

2. Berdasarkan harga, PT $X$ memposisikan produk yang dijual dengan produk berkualitas dengan harga yang rasional.

\section{Bauran Pemasaran (Marketing Mix)}

Berikut adalah bauran pemasaran dari PT X:

1. Produk (Product)

Produk utama yang ditawarkan adalah pewarna cat dalam bentuk padat diluar Titanium Dioxide. Produk yang dipasarkan adalah produk berkualitas yang diperoleh melalui impor dari pemasok.

2. Harga (Price)

Dalam penentuan harga, harga selalu dihitung dapat menutupi biaya dan menghasilkan laba. Penjualan dengan harga rendah dapat dilakukan melalui sebuah pertimbangan strategis.

3. Distribusi (Place)

Untuk mendukung ketersediaan barang ke konsumen, PT X memiliki gudang dan armada pengiriman di Jakarta dan Surabaya. Untuk kota lainnya menggunakan ekspedisi.

\section{Promosi (Promotion)}

Penjualan melalui sales force menjadi hal yang terpenting karena industri yang dilayani adalah B2B. Sehingga pelatihan dan kualitas dari sales sangat penting. Komunikasi massal juga tetap dilakukan melalui iklan dan pameran. 


\section{KESIMPULAN DAN SARAN}

Dari analisa diatas, berikut adalah kesimpulan yang dapat dibuat:

1. Posisi PT X untuk market pewarna cat adalah follower, sehingga PT X harus memperbesar pasar dan melakukan attack strategy.

2. Dengan kemampuan R\&D, perusahaan harus lebih aktif dalam mencari produk baru yang berkualitas untuk menambah portofolio.

3. Menambah jumlah customer dan meningkatkan jenis barang yang dibeli customer. Selain itu hubungan dengan konsumen harus dijaga dengan baik.

4. Diperlukan sebuah sistem kerja yang baik dengan didukung teknologi sehingga perusahaan dapat menjalan proses bisnis dengan lebih baik.

5. Karyawan yang terlatih dan termotivasi dengan baik adalah modal yang penting untuk sebuah perusahaan dalam menjalankan usahanya.

6. Engagement karyawan adalah sesuatu yang penting dan harus dibangun, yang diharapkan dapat menurunkan turn over karyawan.

Berdasarkan hasil analisa, kesimpulan dan juga diskusi dengan pimpinan perusahaan, berikut adalah saran agar perusahaan dapat meningkatkan pemasaran:

1. Meningkatkan pangsa pasar, melalui portofolio produk yang lebih lengkap.

2. Melakukan branding perusahaan baik ke luar (untuk kepentingan ke konsumen dan pemasok) dan juga branding ke dalam (untuk kepentingan engagement karyawan).

3. Melakukan evaluasi sistem kerja, remunerasi, dan reward yang seimbang sehingga karyawan dapat bekerja dengan lebih baik.

4. Peningkatan kemampuan dari Divisi HR, sehingga karyawan yang ada lebih berkualitas dengan menyediakan pelatihan yang diperlukan.

5. Pelatihan untuk level managerial, sehingga dapat menjalankan fungsinya dengan lebih baik dan juga dapat melakukan pendelegasian yang lebih baik.

\section{DAFTAR KEPUSTAKAAN}

David, Fred R. (2013). Strategic Management : Concepts and Cases (14 ${ }^{\text {th }}$ Edition). England: Pearson.

Dogra, Balram. (2010). Rural Marketing: Concepts and Practices. New Delhi: Tata McGraw Hill Publishing Company Limited.

Frost \& Sullivan. (2017, May). Independent Market Research on the Paint and Coating Industry in Selected Southeast Asian Countries. Final Report

Hutt, Michael, D., \& Speh, Thomas, W. (2013). Business Marketing Management: B2B $\left(11^{\text {th }}\right.$ Edition). USA: South-Western, Cengage Learning.

Jobber, David (2009). Principles and Practice of Marketing. McGraw-Hill Higher Education.

Kotler, Philip., \& Armstrong, Gary. (2016). Principles of Marketing (15 ${ }^{\text {th }}$ Edition). New Jersey: Pearson Prentice Hall.

Kotler, Philip., \& Keller, Kevin L. (2012). Marketing Management. (14 ${ }^{\text {th }}$ Edition). England: Pearson Education.

Kumar., \& Reinartz, Werner. (2012). Customer Relationship Management Concept, Strategy, and Tools. Heidelberg: Springer.

Porter, Michael. (2008). Competitive Strategy: Techniques for Analyzing Industries and Competitor. New York: The Free Press.

Stavros, J., \& Hinrich, Gina. (2009). Thin Book of SOAR: Building Strength-Based Strategy. USA: Thin Book Publishing. 
Stavros, J., Cooperrider, D. L., \& Kelley, D. L. (2003). Strategic inquiry appreciative intent: inspiration to SOAR, a new framework for strategic planning. AI Practitioner.

Subdirectorate of Import Statistics (2015). Foreign Trade Statistics 2015, Import, Volume 1. Indonesia: BPS-Statistics.

Website Wordlbank: https://data.worldbank.org/country/indonesia?locale=id

Website CNNIndonesia: www.cnnindonesia.com/ekonomi/20170801101835-78-

231618/mencermati-turunnya-daya-beli-di-tengah-tren-inflasi-rendah 


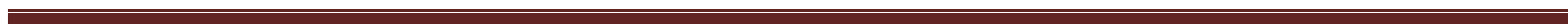
$\cdot$ 